\title{
Integrated Effects of Vermicompost and Nitrogen on Yield and Yield Components of Tomato (Lycopersicum esculentum L.) in Lowlands of Eastern Harerghe
}

\author{
Gebisa Benti $^{1,}{ }^{*}$, Fikadu Tadesse ${ }^{1}$, Gezu Degefa ${ }^{1}$, Mohammed Jafar ${ }^{1}$, Alemayehu Biri ${ }^{2}$ \\ ${ }^{1}$ Horticulture Research Team, Fedis Agricultural Research Center, Harar, Ethiopia \\ ${ }^{2}$ Agronomy Research Team, Fiche Agricultural Research Center, Fiche, Ethiopia
}

Email address:

bantiig@gmail.com (G. Benti)

${ }^{*}$ Corresponding author

To cite this article:

Gebisa Benti, Fikadu Tadesse, Gezu Degefa, Mohammed Jafar, Alemayehu Biri. Integrated Effects of Vermicompost and Nitrogen on Yield and Yield Components of Tomato (Lycopersicum esculentum L.) in Lowlands of Eastern Harerghe. Plant. Vol. 9, No. 3, 2021 , pp. 81-87. doi: 10.11648/j.plant.20210903.16

Received: June 7, 2021; Accepted: August 13, 2021; Published: September 26, 2021

\begin{abstract}
Organic fertilizers improve the soil texture, structures, aeration and allow it to hold water longer, and increase the bacterial and fungal activity in the soil. So, they not only assist your plants, they help the soil. Increasing the use of organic fertilizers and minimizing the use of chemical fertilizers lead to sustainable production of food for human being. Shifting crop production to the use of organic fertilizers can minimize the cost of purchasing chemical fertilizers. Insufficient amount of nutrients in the soil is also among the main factors which constrained productivity of the tomato. Due to this gap the experiment was conducted in Sofi district, Harari People Regional State, Ethiopia in 2016 and 2017 cropping season to investigate the effect of vermicompost and nitrogen rate on yield and yield components of tomato. Experimental treatments were vermicompost rate $\left(0,1.4,2.8\right.$ and $\left.4.2 \mathrm{t} \mathrm{ha}^{-1}\right)$ and nitrogen rate $\left(0,50,100\right.$ and $\left.150 \mathrm{~kg} \mathrm{ha}^{-1}\right)$. A total of 16 treatments were laid out in Randomized Complete Block Design (RCBD) in factorial arrangement with three replications. Melkashola Variety was used for the experiment. The result showed that plant height was significantly $(\mathrm{P}<0.05)$ influenced by the application of vermicompost while number of branches, number of clusters, number of fruits, average fruit weight and fruit yield were significantly $(\mathrm{P}<0.05)$ affected due to the interaction effect of vermicompost and nitrogen.. The highest plant height was rerecorded at $2.8 \mathrm{tha}^{-1}$ of vermicompost whereas the lowest was for the rest rates. Maximum number of clusters, number of fruits and fruit yield were obtained at combined application of $2.8 \mathrm{t} \mathrm{ha}^{-1}$ of vermicompost with $100 \mathrm{~kg} \mathrm{ha}^{-1} \mathrm{~N}$ while maximum number of branches and average fruit weight were recorded at $2.8 \mathrm{t} \mathrm{ha}^{-1}$ with $150 \mathrm{~kg} \mathrm{ha}^{-1} \mathrm{~N}$ and $4.2 \mathrm{t} \mathrm{ha}^{-1}$ with $50 \mathrm{~kg} \mathrm{ha}^{-1} \mathrm{~N}$ respectively. Maximum economic return $\left(461,606 \mathrm{birr} \mathrm{ha}^{-1}\right)$ was also recorded at $2.8 \mathrm{t} \mathrm{ha}^{-1}$ and $100 \mathrm{~kg} \mathrm{ha}^{-1}$ vermicompost and nitrogen, respectively with acceptable marginal rate of return. In general, the combination of vermicompost and nitrogen at 2.8 $\mathrm{tha}^{-1}$ and $100 \mathrm{~kg} \mathrm{ha}^{-1}$ was the best combination for the study area.
\end{abstract}

Keywords: Melkashola, Nitrogen, Tomato, Vermicompost

\section{Introduction}

Tomato (Solanum lycopersicum) is one of the important vegetable crops grown throughout the world and ranks next to the potato and sweet potato in terms of area, but ranks first as a processing crop [12]. The cultivated area under tomato was 4100 hectares with a total production in Ethiopia of 51000 metric tons [13]. Tomato is grown in the summer and winter seasons in Ethiopia; however, production varies in various regions due to varieties, seasons, and climatic conditions, planting time, management practices and soil properties $[14,26]$.

Most soils in Africa are poor compared with other parts of the world [4]. African soil nutrient balances are often negative due to a low level of fertilizer inputs, and soil nutrient depletion is a major reason for decreasing or stagnation of agricultural productivity [34]. The report of [24] also asserts that soil fertility is a major overriding 
constraint that affects all aspects of crop production. As is the case in other regions in Africa, local farmers use inadequate nutrient inputs, inappropriate quality and inefficient combinations of fertilizers, which in the end prove to be very costly [30]. A consequence of this trend is a deeply unbalanced soil nutrient composition that ultimately leads to a reduction in crop yield potential [37]. Nutrients, when in adequate quantity, increases fruit quality, fruit size, colour, and fruit taste of tomato [3].

The organic production system aims at supporting and sustaining healthy ecosystems, soil, farmers, food production, the community, and the economy. Reduction and elimination of the adverse effects of synthetic fertilizers and pesticides on human health and the environment is a strong indicator that organic agriculture is gaining worldwide attention [1, 7]. Organic fertilizers are environmentally friendly, since they are from organic sources [29]. The current global scenario firmly emphasizes the need to adopt eco-friendly agricultural practices for sustainable food production.

Organic fertilizer; vermicompost are produced through the interaction between earthworm and microorganism by the breakdown of organic wastes. It is a stabilized, finely-divided peat-like material with a low $\mathrm{C}$ : $\mathrm{N}$ ratio and high water holding capacity that constitute a source of plant nutrition which is released gradually through mineralization whenever the plant needs it [22]. Earlier work by [35] on the growth and nutrient status of vegetables have revealed a positive effect on plant nutrition, photosynthesis, chlorophyll content and nutrient content of different plant components namely roots, shoots and fruits.

Earthworms play a vital role in plant growth and productivity. The ability of some species of earthworm to consume and breakdown a wide range of organic residues such as sewage sludge, animal wastes, crop residues and industrial refuse is well known [8, 18]. Recycling bio-waste of different resources in the form of compost can be an alternative to meet the increasing demands for organic manures; this will also help to reduce environmental pollution arising out of accumulated bio-wastes [19]. Biowastes could be recycled by adopting simple and suitable techniques in compost making and preparing enriched manure. These improved technologies not only reduce the quantity but also improve the quality of compost with better plant nutrients [16].

There is accumulating scientific evidence that vermicompost can influence the growth and productivity of plants significantly [9]. The study conducted by [36] and [2] showed that growth and yield parameters such as leaf area, dry shoot weights and weight of fruits were significantly affected by applying vermicompost. The report of [23] also stated that tomato yields in field soils amended with compost were significantly greater than those in the untreated plots. The available nutrient status of soil was greatly enhanced by the application of vermicompost as an organic source [32]. Vermicompost enhanced phosphorous concentration and uptake in soil, increasing the solubilisation of phosphorous either by microorganism activation with excretion of organic acids likes citric, glutamic, tartaric, succinic, lactic, oxalic, malic and fumaric [33].

Nitrogen is the most limiting nutrient to crop production [31]. Like many vegetables, tomato is often heavily fertilized. Large amounts of nitrogen are often lost to leaching below the root-zone of vegetable crops [31]. Nitrogen deficiency can seriously decrease yield and crop quality. The nitrogen composition of plant tissue has important nutritional consequences, since plants are a major source of proteins in human diet [5]. Nitrogen is also a constituent of a large number of important compounds found in living cells, such as (enzymes) amino acids and nucleic acids (RNA and DNA) [20]. Hence, nitrogen is critical in improving growth, yield and quality of vegetable crops.

In Eastern Ethiopia, vegetable crops, especially tomato is produced in both season in winter and summer under irrigation and rain fed. Heavy doses of chemical fertilizers in irrigation and pesticides are being used by the farmers to get a better yield of various vegetables and field crops. These chemical fertilizers and pesticides decreases soil fertility and causes health problems to the consumers. Due to adverse effects of chemical fertilizers, interest has been stimulated for the use of organic manures and cow dung through collecting and storing during offseason. However, in the study area; there is no information related to recent research work into the effects of vermicompost, nitrogen fertilizer and their combined effect utilization on vegetable crops, particularly on tomato. Therefore, the main aim of this study was to determine the influence of different rates of vermicompost and combination with nitrogen rate on yield and yield parameters of tomato under field conditions.

\section{Materials and Methods}

\subsection{Experimental Site}

The Experiment was conducted in Sofi district, Harari, Ethiopia, on farmers land. The district was geographically lies at an altitude of 1300-1800 meters above sea level. The mean annual maximum and minimum rain fall is $500 \mathrm{~mm}$ and $300 \mathrm{~mm}$, respectively. Like some part of Ethiopia, Sofi district is characterized by the bimodal rainfall pattern. The first season is characterized by the short rainy season (Belg), which extends from March to May, while the second season is the most important main rainy season (Meher) which extends from July to October. The dry-spell period extends from June to July and based on its duration, it may affect crop growth. The minimum and maximum temperature of the area is $25^{\circ} \mathrm{C}$ and $35^{\circ} \mathrm{C}$, respectively with the annual average of $30^{\circ} \mathrm{C}$ (Harari BoA, 2016, unpublished).

\subsection{Experimental Treatments and Design}

For this experiment, tomato variety "Melkashola" was used as a test crop which was potentially produced by the farmers' in the area. The experimental treatments consisted of four vermicompost $\left(0,1.4,2.8\right.$ and 4.2 tons $\left.\mathrm{ha}^{-1}\right)$ and four nitrogen fertilizer rates $\left(0,50,100\right.$ and $\left.150 \mathrm{~kg} \mathrm{~N} \mathrm{ha}^{-1}\right)$. A total 
of 16 treatments were laid out in Randomized Complete Block Design (RCBD) in factorial arrangement with three replications. Each treatment combination was assigned randomly to experimental units within a block. The plant and row spacing of $30 \mathrm{~cm}$ and $70 \mathrm{~cm}$, respectively, was used for all treatments. A plot size of $2.1 \mathrm{~m}$ in width and $2.1 \mathrm{~m}$ in length were used. Each plot consisted of four rows and about eight plants were planted per row. Data were recorded from the two central rows of each plot.

\subsection{Experimental Procedures}

The experimental field was cultivated to a depth of 25-30 $\mathrm{cm}$ by a tractor. The experimental plots were harrowed to a fine tilth manually before planting. The beds were supplied with supplementary irrigation during the shortage of rainfall. Finally, hardened, healthy and uniform seedlings of pencil size were transplanted at 3 to 5 leaves developed. All cultural practices were conducted as per recommendation of the area and each and every data planned to be collected were taken on time by using data record sheet. The nitrogen fertilizer (N) was applied uniformly in the form of urea whereas phosphorus (P) in the form of Triple Super phosphate (TSP) during sowing of the seed on nursery.

Earthworms were collected from Haramaya University for this experiment. Vermicompost was prepared by feeding earthworms with different weeds and cow dung through wetting with water frequently. These inputs were estimated to the cost of vermicompost preparation. Vermicompost was applied to the field according to specified rate before transplanting seedlings into the field. Nitrogen was applied at two equal splits ( 3 weeks after transplanting and the rest half 6 weeks after transplanting) as basal application according to the rate specified in the treatments. All treatments were randomly assigned to the experimental plots.

\subsection{Data Analysis and Management}

\subsubsection{Data Collected}

Data were collected from plant height $(\mathrm{cm})$, number of branch per plant, number of cluster per plant, number of fruit per cluster, number of fruits per plant, yield per hectare, average fruit weight. Plant height was measured using ruler from the base of the plant to the tip of the shoots from ten plants of the central rows. The average numbers of branches were counted from ten plants. The numbers of clusters per plant and average numbers of fruits per cluster were counted from ten plants of the central rows. All fruits harvested were counted to estimate the number of fruits per plant. The average fruit weight was weighted from ten fruits which harvested from central rows of the plots. The average fruit weight was expressed in gram. During harvesting, all harvest cycle fruits were weighted by using digital balance and expressed in tons per hectare.

\subsubsection{Statistical Data Analysis}

Data were subjected to analysis of variance using GenSTAT Statistical Software package. Means that differed significantly were separated using the LSD (Least Significant
Difference) test at 5\% level of significance.

\section{Result and Discussion}

\subsection{Soil Chemical Properties}

The analysis of soil sample for experimental site (Table 1) indicated that the soil was sandy clay loam in texture and moderately basic in reaction $(\mathrm{pH}=8)$. According to [6] range, the soil was medium in total nitrogen $(0.171 \%)$. Similarly, according to [28], the experimental site had low available phosphorus (2.893 $\mathrm{mg} \mathrm{kg}^{-1}$ soil). According to [10] range of organic matter content of soil, the experimental soil had moderate organic matter (2.277) contents. This moderate content of organic matter indicated that the experimental soil was moderate in structural condition and stability. According to [25], the soil of the experimental site had low cation exchange capacity $\left(7.13 \mathrm{cmol} \mathrm{kg}{ }^{-1}\right.$ soil) and high in exchangeable potassium $\left(9.026 \mathrm{cmol}(+) \mathrm{kg}^{-1}\right.$ soil) (Table 1$)$.

Vermicompost was also analysed and the physical texture was observed as clay loam. The $\mathrm{pH}$ of the vermicompost was mildly alkaline (7.7). The $\mathrm{pH}$ of vermicompost from different wastes have also been reported like sheep manure of 8.6 [15], sewage sludge $\mathrm{pH}$ of 7.2 [21]. Vermicompost contained very high total nitrogen, available phosphorous, exchangeable potassium, organic carbon and CEC as indicated in the result (Table 1).

\subsection{Plant Height and Number of Branches}

The result revealed that vermicompost significantly $(\mathrm{P}<0.05)$ affected plant height (Figure 1). Increasing vermicompost from nil to $2.8 \mathrm{t} \mathrm{ha}^{-1}$ linearly increased plant height though it was statistically parity. Plant height was declined beyond $2.8 \mathrm{t} \mathrm{ha}^{-1}$ vermicompost. Thus, application of $2.8 \mathrm{t} \mathrm{ha}^{-1}$ vermicompost recorded the highest plant height $(72.32 \mathrm{~cm})$ while the lowest value $(66.48 \mathrm{~cm})$ was at $4.2 \mathrm{t} \mathrm{ha}^{-1}$. In line with current result, [17] stated that application of vermicompost at $\left(20 \mathrm{t} \mathrm{ha}^{-1}\right)$ and NPK fertilizer $\left(200 \mathrm{~kg} \mathrm{ha}^{-1}\right)$ showed an increment of $36.34 \mathrm{~cm}$ and $23.34 \mathrm{~cm}$ of shoot length respectively, as compared to control.

On the other hand, number of branches were significantly $(\mathrm{P}<0.05)$ affected due to combined application of vermicompost and nitrogen fertilizer. The highest numbers of branches were recorded at $2.8 \mathrm{tha}^{-1}$ vermicompost with 150 $\mathrm{kg} \mathrm{ha}^{-1}$ nitrogen while the lowest was recorded at $2.8 \mathrm{t} \mathrm{ha}^{-1}$ with $0 \mathrm{~kg} \mathrm{ha}^{-1}$ nitrogen (Table 2). Plant growth parameters such as shoot length, root length, number of leaves, fresh weight and dry weights were better in vermicompost treated plants rather than the control plant [38].

\subsection{Clusters and Fruits per Plant}

Clusters and fruits per plant were significantly $(\mathrm{P}<0.05)$ affected due to the interaction effect of vermicompost and nitrogen application. Combined application of vermicompost with nitrogen at the rate of $2.8 \mathrm{t} \mathrm{ha}^{-1}$ and $100 \mathrm{~kg} \mathrm{ha}^{-1}$ recorded the highest number of clusters (16.9) and fruits per plant (51.4) while the lowest value was observed at control 
treatment (Tables 2 and 3). Increasing application of vermicompost from nil to $2.8 \mathrm{t} \mathrm{ha}^{-1}$ linearly increased fruit clusters at application of $100 \mathrm{~kg} \mathrm{ha}^{-1}$ nitrogen. Application of vermicompost and nitrogen at $2.8 \mathrm{t} \mathrm{ha}^{-1}$ and $100 \mathrm{~kg} \mathrm{ha}^{-1}$, respectively, resulted in an increment of about $55 \%$ fruit clusters and $50.6 \%$ fruits per plant respectively over the control treatment. According to the study of [27], the number of fruits per plant, fruit yield per plant, fruit yield per plot and tomato yield were significantly affected by combined use of organic and inorganic fertilizer.

\subsection{Average Fruit Weight and Fruit Yield}

Average fruit weight and fruit yield were significantly $(\mathrm{P}<0.05)$ affected due to the interaction effect of vermicompost and nitrogen fertilizer. The highest average fruit weight (74.9 g) was recorded at combined application of $4.2 \mathrm{t} \mathrm{ha}^{-1}$ vermicompost and $50 \mathrm{~kg} \mathrm{ha}^{-1}$ nitrogen while lowest value was recorded for control treatment. On the other hand, the highest fruit yield $\left(65.3 \mathrm{tha}^{-1}\right)$ was recorded at combined application $2.8 \mathrm{t} \mathrm{ha}^{-1}$ vermicompost and $100 \mathrm{~kg} \mathrm{ha}^{-1}$ nitrogen fertilizer. The result revealed that combined application of $2.8 \mathrm{t} \mathrm{ha}^{-1}$ vermicompost and $100 \mathrm{~kg} \mathrm{ha}^{-1}$ nitrogen resulted in an increment of $54.7 \%$ to $56.7 \%$ fruit yield as compared to combined application of $0 \mathrm{~kg} \mathrm{ha}^{-1}$ vermicompost with all the rest nitrogen rates (Table 4). In line with this study, [17] also reported that application of cow manure vermicompost had significantly influenced all the studied growth parameters and fruits yield of tomato plant rather than inorganic nitrogen fertilizer.

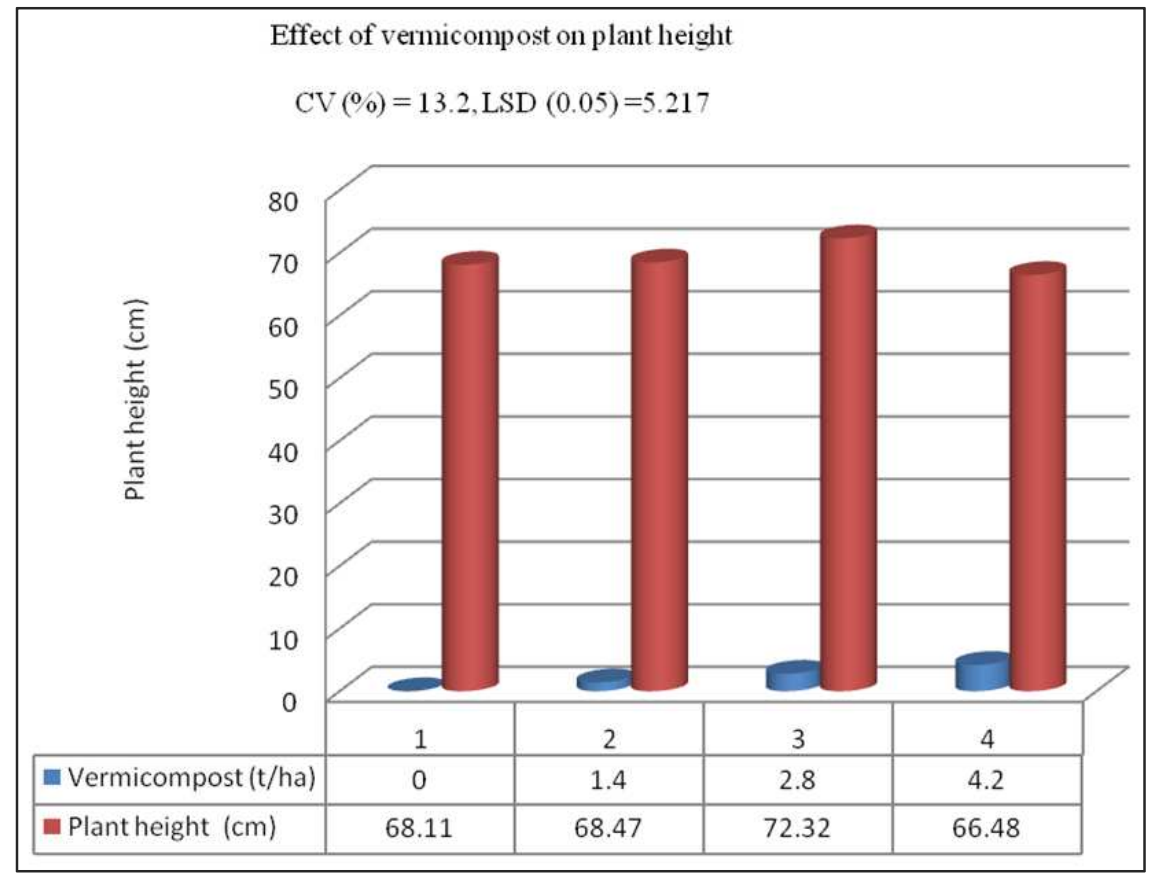

Figure 1. Effect of vermicompost on plant height of tomato.

Table 1. Soil and vermicompost physical and chemical properties of the experimental site.

\begin{tabular}{|c|c|c|c|c|c|c|c|c|c|c|}
\hline \multirow{2}{*}{ Samples } & \multirow{2}{*}{$\mathbf{p H}$} & \multirow{2}{*}{ CEC } & \multirow{2}{*}{ OC } & \multirow{2}{*}{$\mathrm{Mg}^{2+}$} & \multirow{2}{*}{$\mathrm{Ca}^{2+}$} & Exch. & Exch. & \multirow{2}{*}{ Avail P } & \multirow{2}{*}{$\mathbf{T N}$} & \multirow{2}{*}{ Texture } \\
\hline & & & & & & $\mathbf{N a}$ & $\mathbf{K}$ & & & \\
\hline Soil & 8.00 & 7.13 & 1.32 & 9.36 & 8.96 & 0.40 & 9.03 & 2.89 & 0.17 & Sandy clay loam \\
\hline Vermicompost & 7.70 & 27.83 & 8.16 & 29.95 & 18.55 & 0.40 & 35.43 & 39.26 & 0.58 & Clay loam \\
\hline
\end{tabular}

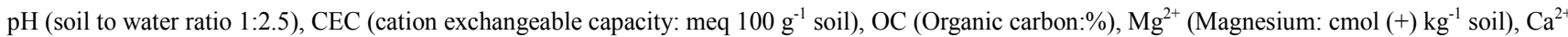
(Calcium: cmol (+) $\mathrm{kg}^{-1}$ soil), Exch. Na (Exchangeable Sodium: cmol (+) $\mathrm{kg}^{-1}$ soil), Exch. K (Exchangeable Potassium: $\mathrm{cmol}^{(+)} \mathrm{kg}^{-1}$ soil), Avail. P (Available phosphorous: $\mathrm{mg} \mathrm{kg}^{-1}$ soil), TN (Total Nitrogen: \%).

Table 2. Interaction effect of vermicompost and nitrogen rate on branches and fruit clusters per plant over the two years (2016 and 2017).

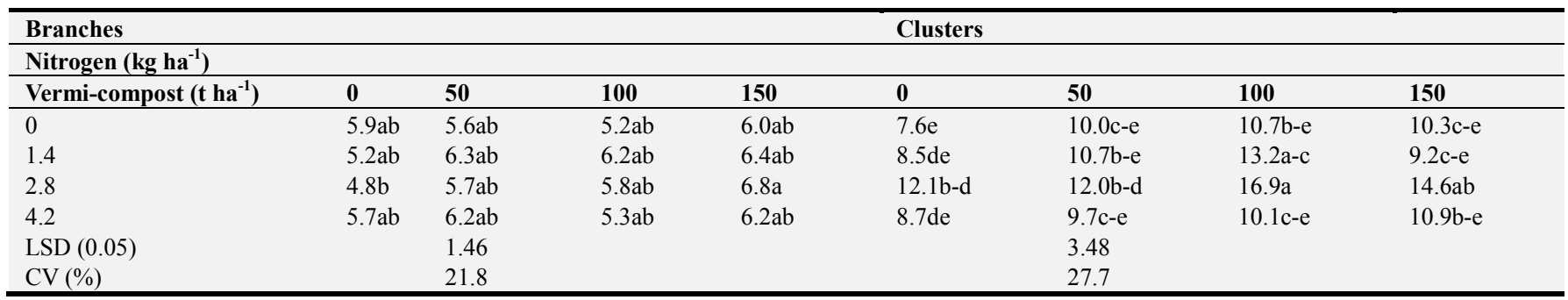


Table 3. Interaction effect of vermicompost and nitrogen fertilizer on fruit weight and number of fruits per plant for the 2016 and 2017.

\begin{tabular}{|c|c|c|c|c|c|c|c|c|}
\hline \multirow{2}{*}{ Nitrogen $\left(\mathrm{kg} \mathrm{ha}^{-1}\right)$} & \multicolumn{4}{|c|}{ Average Fruit weight (g) } & \multicolumn{4}{|c|}{ Fruits per plant } \\
\hline & & & & & & & & \\
\hline Vermi Compost $\left(\mathrm{t} \mathrm{ha}^{-1}\right)$ & $\mathbf{0}$ & 50 & 100 & 150 & $\mathbf{0}$ & 50 & 100 & 150 \\
\hline 0 & $42.9 \mathrm{f}$ & $65.3 \mathrm{a}-\mathrm{c}$ & $53.8 \mathrm{~b}-\mathrm{f}$ & $61.4 \mathrm{a}-\mathrm{d}$ & $25.4 \mathrm{f}$ & $26.4 \mathrm{ef}$ & $27.6 \mathrm{~d}-\mathrm{f}$ & $27.6 \mathrm{~d}-\mathrm{f}$ \\
\hline 1.4 & $46.0 \mathrm{ef}$ & $66.6 \mathrm{a}-\mathrm{c}$ & $56.5 \mathrm{~b}-\mathrm{e}$ & $61.5 \mathrm{a}-\mathrm{d}$ & $28.5 \mathrm{~d}-\mathrm{f}$ & $36.1 b-f$ & $39.2 b-d$ & $37.7 b-f$ \\
\hline 2.8 & $48.7 \mathrm{~d}-\mathrm{f}$ & $67.7 \mathrm{ab}$ & $56.8 \mathrm{~b}-\mathrm{e}$ & $62.0 \mathrm{a}-\mathrm{d}$ & $27.6 \mathrm{~d}-\mathrm{f}$ & $38.3 \mathrm{~b}-\mathrm{e}$ & $51.4 \mathrm{a}$ & $48.3 \mathrm{ab}$ \\
\hline 4.2 & $52.9 \mathrm{c}-\mathrm{f}$ & $74.9 \mathrm{a}$ & $58.4 \mathrm{~b}-\mathrm{e}$ & $62.2 \mathrm{a}-\mathrm{d}$ & $28.6 \mathrm{~d}-\mathrm{f}$ & $32.2 \mathrm{c}-\mathrm{f}$ & $41.1 \mathrm{a}-\mathrm{c}$ & $37.5 b-f$ \\
\hline $\operatorname{LSD}(0.05)$ & & 11.89 & & & & 10.662 & & \\
\hline CV $(\%)$ & & 17.7 & & & & 26.8 & & \\
\hline
\end{tabular}

Table 4. Interaction effect of vermicompost and nitrogen fertilizer on fruit yield over the two years (2016 and 2017).

\begin{tabular}{|c|c|c|c|c|}
\hline \multicolumn{5}{|l|}{ Nitrogen $\left(\mathrm{kg} \mathrm{ha}^{-1}\right)$} \\
\hline Vermicompost $\left(\mathrm{t} \mathrm{ha}^{-1}\right)$ & $\mathbf{0}$ & 50 & 100 & 150 \\
\hline 0 & $29.6 b$ & $29.6 b$ & $28.7 b$ & $28.3 b$ \\
\hline 1.4 & $31.2 \mathrm{~b}$ & $45.9 \mathrm{ab}$ & $53.5 \mathrm{ab}$ & $40.3 \mathrm{ab}$ \\
\hline 2.8 & $45.9 \mathrm{ab}$ & $44.9 \mathrm{ab}$ & $65.3 \mathrm{a}$ & $54.5 \mathrm{ab}$ \\
\hline 4.2 & $30.6 \mathrm{ab}$ & $33.7 b$ & $50.8 \mathrm{ab}$ & $48.5 \mathrm{ab}$ \\
\hline $\operatorname{LSD}(0.05)=$ & 25.09 & $\mathrm{CV}(\%)$ & $=25.8$ & \\
\hline
\end{tabular}

\subsection{Partial Cost Analysis}

The partial cost analysis was conducted based on the average price fluctuation of tomato in two years. At local market, the price of tomato is about 8 birr kg-1, but fluctuate through times. The total variable costs were the combinations of fertilizer, vermicompost (crop residues, water, cow dung) and labor costs. The combined application of vermicompost and nitrogen at $2.8 \mathrm{t} \mathrm{ha}^{-1}$ and $100 \mathrm{~kg} \mathrm{ha}^{-1}$, respectively, was resulted maximum net return of 461,606 birr ha ${ }^{-1}$ with acceptable marginal rate of return. Application of nitrogen without vermicompost recorded the lowest net returns in all treatments.

Table 5. Partial budget analysis of vermicompost and nitrogen applied on tomato.

\begin{tabular}{|c|c|c|c|c|c|c|}
\hline$($ Vermi $+\mathbf{N})$ & UFY $\left(\mathrm{kg} \mathrm{ha}^{-1}\right)$ & $\operatorname{AFY}\left(\mathrm{kg} \mathrm{ha}^{-1}\right)$ & GR (birr ha-1) & TVC (birr ha' $\left.{ }^{-1}\right)$ & NR (birr ha ${ }^{-1}$ ) & MRR (\%) \\
\hline $0-0$ & 29610 & 26649 & 213192 & 2894 & 210298 & \\
\hline $0-50$ & 29600 & 26640 & 213120 & 5074 & 208046 & D \\
\hline $0-100$ & 28700 & 25830 & 206640 & 5654 & 200986 & D \\
\hline $1.4-0$ & 31200 & 28080 & 224640 & 5944 & 218696 & 6107 \\
\hline $0-150$ & 28300 & 25470 & 203760 & 6234 & 197526 & $\mathrm{D}$ \\
\hline $1.4-50$ & 45900 & 41310 & 330480 & 6544 & 323936 & 40777 \\
\hline $1.4-100$ & 53500 & 48150 & 385200 & 7104 & 378096 & 9671 \\
\hline $2.8-0$ & 45900 & 41310 & 330480 & 7394 & 323086 & D \\
\hline $1.4-150$ & 40300 & 36270 & 290160 & 7684 & 282476 & D \\
\hline $2.8-50$ & 44900 & 40410 & 323280 & 7974 & 315306 & 11321 \\
\hline $2.8-100$ & 65300 & 58770 & 470160 & 8554 & 461606 & 25224 \\
\hline $4.2-0$ & 30600 & 27540 & 220320 & 8904 & 211416 & $\mathrm{D}$ \\
\hline $2.8-150$ & 54500 & 49050 & 392400 & 9134 & 383266 & 74717 \\
\hline $4.2-50$ & 33700 & 30330 & 242640 & 9484 & 233156 & D \\
\hline $4.2-100$ & 50800 & 45720 & 365760 & 10064 & 355696 & 21128 \\
\hline $4.2-150$ & 48500 & 43650 & 349200 & 10644 & 338556 & $\mathrm{D}$ \\
\hline
\end{tabular}

Note: UFY=Unadjusted Fruit Yield, AFY Adjusted Fruit Yield=, GR $=$ Gross return, $T V C=$ Total Variable Cost, NR= Net Return, MRR=Marginal rate of Return.

\section{Conclusion}

The experiment was conducted for two consecutive cropping season to determine the effect of Vermicompost and nitrogen fertilizer rate on tomato yield and yield parameters. The soil of the area needs additions of nutrients for the optimum growth of the crop. The result over the two years revealed that there were significant differences among treatments for plant height due to the application of vermicompost. Significant differences also observed among the treatments for number of branches, number of clusters, fruits per plant, average fruit weight and fruit yield due to the interaction effect of vermicompost and nitrogen. Generally, application of vermicompost at $2.8 \mathrm{tha}^{-1}$ and nitrogen at 100 $\mathrm{kg} \mathrm{ha}^{-1}$ recorded the highest number of branches, number of clusters, number of fruit per plant and fruit yield. The highest economic return was 461,606 birr ha $^{-1}$ with acceptable marginal rate at $2.8 \mathrm{t} \mathrm{ha}^{-1}$ vermicompost and $100 \mathrm{~kg} \mathrm{ha}^{-1}$ nitrogen application. The combined application of $2.8 \mathrm{t} \mathrm{ha}^{-1}$ vermicompost and $100 \mathrm{~kg} \mathrm{ha}^{-1}$ nitrogen were resulted 2.2 times net return than control treatment. Therefore, application of $2.8 \mathrm{t} \mathrm{ha}^{-1}$ vermicompost and $100 \mathrm{~kg} \mathrm{ha}^{-1}$ nitrogen was recommended for tomato production to the 
study area and similar agro-ecology.

\section{Acknowledgements}

The authors greatly indebted to acknowledge the Oromia Agricultural Research Institute and AGP-II for funding the study. We would like to grateful Ato Jemal Jibril the owner of the experimental field' for his commitment to manage the experimental field. Our heartfelt thanks also go to all staff members of the Fedis Agricultural Research Center for their support in ideas and facilitation for the success of this study.

\section{References}

[1] Aksoy, U. 2001. Ecological farming. II. In Proceedings of the Ecological Farming Symposium, Antalya, Turkey, 14-16 December 2001.

[2] Atiyeh, R. M., Arancon, N, Edwards, C. A and Metzger, T. D. 2000. Influence of earthworm processed pig mature on the growth and yield of greenhouse tomatoes. Sci. Direst, 75: 175180.

[3] Azad, A. K. 2000. Effects of plant spacing, source of nutrients and mulching on growth and yield of cabbage. M. Sc. Thesis. Department of Horticulture, Bangladesh Agriculture University Mymensingh, pp. 15-40.

[4] Bationo A., Hartemink A., Lungu O., Naimi M., Okoth P., Smaling E., Thiombiano L. 2006. African soils: their productivity and profitability of fertilizer use, Background papers prepared for the African fertilizer summit, Abuja, Nigeria, $25 \mathrm{p}$

[5] Below, F. E. 1995. Nitrogen metabolism and crop productivity. P. 385. In: Mohammed P. 1995. (Eds.). Handbook of plant and crop physiology. Marcel Decker, Inc. New York.

[6] Bruce, R. C., and Rayment, G. E. 1982. Analytical methods and interpretations used by the Agricultural Chemistry Branch for Soil and Land Use Surveys. Queens land Department of Primary Industries. Bulletin QB8 (2004), Indooroopilly, Queensland. chemical fertilizers. Les. Envis. Newsl. 2004, 7, 4-5.

[7] Chowdhury, R. Dominguez, J., Edwards, C. A. and Sulber, S. 2004. Effects of chemical fertilizers on the surrounding environment. A comparison of vermicomposting and composting methods to process animal wastes. Biocycle, 38: $57-59$

[8] Edwards, C. A., Burrows, I., Fletcher, K. E. and Jones, B. A. 1985. The use of earthworms for composting farm waste. In: Composting Agricultural and Other waste, Gasser, J. K. R. (eds). Elsevier, London and New York, ISBN: 0-85334 - 3578, pp: 229-241.

[9] Edwards, C. A. 1998. The use of earthworm in the breakdown and management of Organic wastes. In: earthworm ecology. Edwards, C. A (eds). CRC press LLC, Boca Raton, F1, ISBN: 84931819X, PP: 327-354.

[10] Emerson, W. W. 1991. Structural decline of soil, assessment and prevention. Australian Journal of Soil Research, 29: 905 922.
[11] Follet, R., R. Donahue and L. Murphy, 1981. Soil and Soil Amendments. Prentice hall: Inc., New Jersey.

[12] Food and Agriculture Organization (FAO). 2016. Production Year Book. Food and Agriculture Organization of United Nations, Rome, Italy.

[13] Food and Agriculture Organization (FAO). 2010. Production Year Book; Food and Agriculture Organization of the United Nations: Rome, Italy, Volume 53, pp. 132-133.

[14] Gabal, M. R.; Abd-Allah, I. M.; Hass, F. M.; Hassannen, S. 1984. Evaluation of some American tomato cultivars grown for early summer production in Egypt. Ann. Agric. Sci. Moshtohor J. 22, 487-500.

[15] Gutierrez-Miceli F., J. Santiago-Boraz, JAM Molina, C. C. Nafat, M. Abdul-Archila, M. A. O. Llaven, R. Rincón-Rosales and Dendooven. L. 2007. Vermicompost as a soil supplement to improve growth, yield and fruit quality of tomato (Lycopersicum esculentum). Bioresour. Technol., 98: 27812786.

[16] Jagadeesan, G. 2005. "Resource Recovery of Farm Refuse", Proceedings - UGC sponsored National Seminar on WasteDisposal Management and Utilisation, Department of Mechanical Engineering Faculty of Engineering and Technology, Annamalai University, Annamalai nagar, India. 22-23.

[17] Kashem, M. A., Sarker, A., Hossain, I. and Islam, M. S. 2015. Comparison of the Effect of Vermicompost and Inorganic Fertilizers on Vegetative Growth and Fruit Production of Tomato (Solanum lycopersicum L.). Open Journal of Soil Science, 5, 53-58. http://dx.doi.org/10.4236/ojss.2015.52006.

[18] Kaushik, P. and Garge, V. K. 2003. Vermicomposting of mixed solid textile mill sludge and cow dung with the epigeic earthworm Eisenia foetida. Bioresour. Technol., 90: 311 - 316.

[19] Kumar, A. 2005. "Verms and Vermitechnology", A. P. H Publishing Corporation, New Delhi. 5, 71.

[20] Lea, J. P., and Lee Gold, C. R. 1993. Plant biochemistry and molecular biology. John Wiley and Sons Ltd. Pp. 155-180.

[21] Masciandaro, G., Ceccanti, B., Roachi, V. and Bauer, C. 2000. Kinetic parameters of dehydrogenase in the assessment of the response of soil to vermicompost and inorganic fertilizers. Biology and Fertility of Soils. 32: 479-483.

[22] Mathivanan S, Chidambaram A L A, Sundaramoorthy P, Kalaikandhan R. 2012. Effect of vermicompost on germination and biochemical constituents of ground nut (Arachis hypogea L.) seedling. Int J Res Biol Sci,; 2 (2): 54-59.

[23] Maynard, A. A. 1995. Cumulative effect of annual additions of MSW compost on the yield of field grown tomatoes. Compost Sci. util., 3: 47-54.

[24] Mbah, C. N. 2006. Influence of organic wastes on plant growth parameters and nutrient uptake by maize (Zea mays L.). Nigerian Journal of Soil Science, 16 (1), 104-108.

[25] Metson, A. J. 1961. Methods of chemical analysis for soil survey samples. Soil Bureau Bulletin No. 12, New Zealand Department of Scientific and Industrial Research, pp. 168175. (Government Printer: Wellington, New Zealand.).

[26] Nandwani, D. 2014. Growth and yield response of four tomato cultivars in the US Virgin Islands. J. Agric. Univ. Puerto Rico, 97, 181-184. 
[27] Ogundare, S. K; Babalola, T. S; Hinmikaiye, A. S. and Oloniruha, J. A. 2015. Growth and fruit yield of tomato as influenced by combined use of organic and inorganic fertilizer in Kabba, Nigeria. European Journal of Agriculture and Forestry Research, Vol. 3, No. 3, pp. 48-56.

[28] Olsen, S. R.; Cole, C. V.; Watanabe, F. S. and Deen, L. A. 1954. Estimation of available $\mathrm{P}$ in soils by extraction with sodium bicarbonate. USDA. Circ 939: 1-19.

[29] Oyewole, C.; Opaluwa, H.; Omale, R. 2012. Response of tomato (Lycopersicon esculentum) growth and yield to rates of mineral and poultry manure application in the Guinea Savanna Agro-ecological Zone in Nigeria. J. Biol. Agric. Healthc, 2, 44-56.

[30] Palm, C. A., Myers, R. J. K., \& Nandwa, S. M. 1997. Combined use of organic and inorganic nutrient sources for soil fertility maintenance and replenishment. In R. J. Buresh, P. A. Sanchez, \& F. G. Calhoun (Eds.), Replenishing soil fertility in Africa (pp. 193-218). Madison, WI, USA: Soil Science Society of America (SSSA).

[31] Pionke, H. B, Sharma, M. L, Hirschberg, K. J. 1990. Impact of irrigated horticulture on nitrate concentration in ground water. Agriculture, Ecosystems and Environment 32, 199-122.

[32] Prabha, K. P., Loretta, Y. L., Usha, R. K. 2007. An experimental study of vermi-biowaste composting for agricultural soil improvement. Bioresour. Technol., 99: 16721681.
[33] Sainz, M. T., Taboada-Castro, M. T. and Vilarino, A. 1998. Growth, mineral nutrition and mycorrhizal colonization of red clover and cicumber plants grown in a soil amended with composted urban waste. Plant Soil, 205: 85 - 92.

[34] Sanchez P. A., Shepherd K. D., Soule M. J., Place F. M., Buresh R. J., Izac A.-M. N., Mokwunye A. U., Kwesiga F. R., Ndiritu C. G., Woomer P. L. 1997. Soil fertility replenishment in Africa. An investment in natural resource capital, in: Buresh Research Journal.

[35] Theunissen J, Ndakidemi, P. A, Laubscher C. P. 2010. Potential of Vermicompost produced from plant waste on the growth and nutrient status in vegetable production. Intl J Phys Sci, 5: 1964-1973.

[36] Tomati, U. and Galli, E. 1995. Earthworm, soil fertility and plant productivity. Acta Zoologica Fennica, 196: 11-14.

[37] Tonfack, L. B.; Bernadac, A.; Youmbi, E.; Mbouapouognigni, V. P., Ngueguim, M.; Akoa, M. 2009. Impact of organic and inorganic fertilizers on tomato vigor, yield and fruit composition under tropical andosol soil conditions. Fruits, 64, 167-177.

[38] Vaidyanathan, G. and Vijayalakshmi, A. 2017. Effect of vermicompost on growth and yield of tomato. European Journal of Pharmaceutical and Medical Research, 2017, 4 (9), 653-656. www.ejpmr.com 